\title{
Characteristics of bottom sediments of Lake Widryńskie
}

\author{
Daniel Szymański, Julita Dunalska, Michał Łopata, Izabela Bigaj, Rafał Zieliński
}

Department of Environment Protection Engineering, University of Warmia and Mazury, Prawocheńskiego 1, 10-719 Olsztyn, Poland, email: daniel.szymanski@uwm.edu.pl

\begin{abstract}
The aim of this study was to determine the chemical composition of Lake Widryńskie bottom sediments (max. depth. 27.0 $\mathrm{m}$, area $123.9 \mathrm{ha}$ ). The sampling of bottom sediments was conducted once, on 16 August 2010. Sampling was made in 10 specific areas. Among the 10 samples, 4 samples were taken from the littoral and sublittoral zones, while the rest were taken from the profundal zone. The dominant component of the sediments was silica and calcium carbonates were subdominant. Based on the survey, it was determined that silica occurred in greater numbers in littoral sediments, while in sublittoral sediments there was increased participation in the chemical composition of organic matter. The elements that build a capacity complex were a small percentage of the dry weight of sediment. Sediment from the vicinity of inflows contains higher amounts of silica, which confirmed the impact of the catchment on the chemical composition of sediments.
\end{abstract}

Key words: bottom sediments, chemical composition, littoral, sublittoral, profundal

\section{Introduction and goal of the study}

Increased demand for agricultural products forced farmers to use more nitrogen and phosphorus fertilizers (Siwek et al. 2009). Plants do not use them in their entirety, some part being dispersed in the environment. As a result, depending on the physiographic features, the degree of permeability of soil and climate conditions, a smaller or larger load of nutrient salts reaches water reservoirs with runoff, contributing to increased eutrophication of the reservoir (BajkiewiczGrabowska 2002). The aquatic ecosystem may, to some extent, limit the process by removing some nutrients into the bottom sediments (Januszkiewicz 1970).

Nutrients accumulated in sediments may eventually be put into the water column (Forsberg 1989). The first step in moving compounds deposited in the sediments is the transition phase to interstitial water, and then deoxidation of bottom layers followed by diffusion into the waters lying above. This phenomenon is called "internal loading".

The release of phosphorus from sediments is conditioned by the composition of the sediment sorption complex and the form in which it occurs. Among the most important forms of inorganic phosphorus are labile phosphorus, bound with oxides and hydroxides of aluminium, iron and manganese, phosphorus bound with calcium and residual inorganic phosphorus bound with some of the silicates (Pardo et al. 2003). Among these forms the most mobile fraction is labile phosphorus (Pacini and Gätcher 1999; Kaiserli et al. 2002) and the form bound with iron, because it is prone to changing redox conditions (Hullebush et al. 2003).

The chemical composition of sediments provides information on the rate of eutrophication of water reservoirs. Thus, the objective of this study was to determine the chemical composition of bottom sediments of respective areas of Lake Widryńskie for the conservation action plan for this reservoir.

\section{Material and methods}

Lake Widryńskie (Table 1) is located in northeastern Poland, in the area of the macroregion of the Masurian Lakeland and the mesoregion of the Mrągowo Lakeland (Kondracki 2001). The lake is located in the Łyna River basin, which connects to Lake Legińskie and the River Sajna. Lake Widryńskie is a flow-through lake fed with several small inflows and 
Table 1. Morphometric data for Lake Widryńskie (WIOŚ 2009)

\begin{tabular}{lcc}
\hline \multicolumn{1}{c}{ Parameter } & Unit & Value \\
\hline Lake surface area & ha & 123.9 \\
Volume & dam $^{3}$ & 10557.4 \\
Maximum depth & $\mathrm{m}$ & 27.0 \\
Mean depth & $\mathrm{m}$ & 8.5 \\
Maximum length & $\mathrm{m}$ & 1605 \\
Maximum width & $\mathrm{m}$ & 1300 \\
Shoreline development & - & 1.2 \\
\hline
\end{tabular}

drainage water from the lake is via a channel with nearby Lake Legińskie (Fig. 1).

The total catchment area of the lake is $10.33 \mathrm{~km}^{2}$ (WIOS 2009). In the immediate vicinity of the lake are the villages of Widryny, Leginy and Plenowo. The direct catchment area is small and has an area of 70.4 hectares. The largest share in its land use is agricultural land (44\%) and grassland (23.7\%), and forests and wasteland occupy respectively $20.2 \%$ and $12.1 \%$.

The study of bottom sediments of Lake Widryńskie was conducted in August 2010. The 10 sampling locations were established on the lake: (i) four sites in the littoral zone $(1,3,5,9)$, (ii) four sites in the sublittoral zone $(2,4,6,10)$, and (iii) two sites in the deepest profundal zones $(7,8)$. The ten-centimetre long bottom sediment cores were collected with the Kajak sediment core sampler with a diameter of 52 $\mathrm{mm}$. Bottom sediments were dried at room temperature. After drying, the sediments were ground to a powder in a porcelain mortar. The prepared samples were subjected to chemical analysis. Organic matter content and carbon dioxide were determined in the bottom sediments by the gravimetric method, and nitrogen content with the Kjeldahl method.

The determination of iron, manganese and aluminium were made on the basis of samples mineralized in a mixture of $\mathrm{H}_{2} \mathrm{SO}_{4}, \mathrm{HClO}_{4}, \mathrm{HNO}_{3}$ acids, colorimetrically on a Merck SQ118 spectrophotometer. The calcium content was determined by titration. Residues from filtering mineralized samples after calcination were treated as silica. The content of total and mineral phosphorus and mineral fractions of phosphorus in the sediments was determined according to the methodology specified by Golachowska (1977 a, b, c).

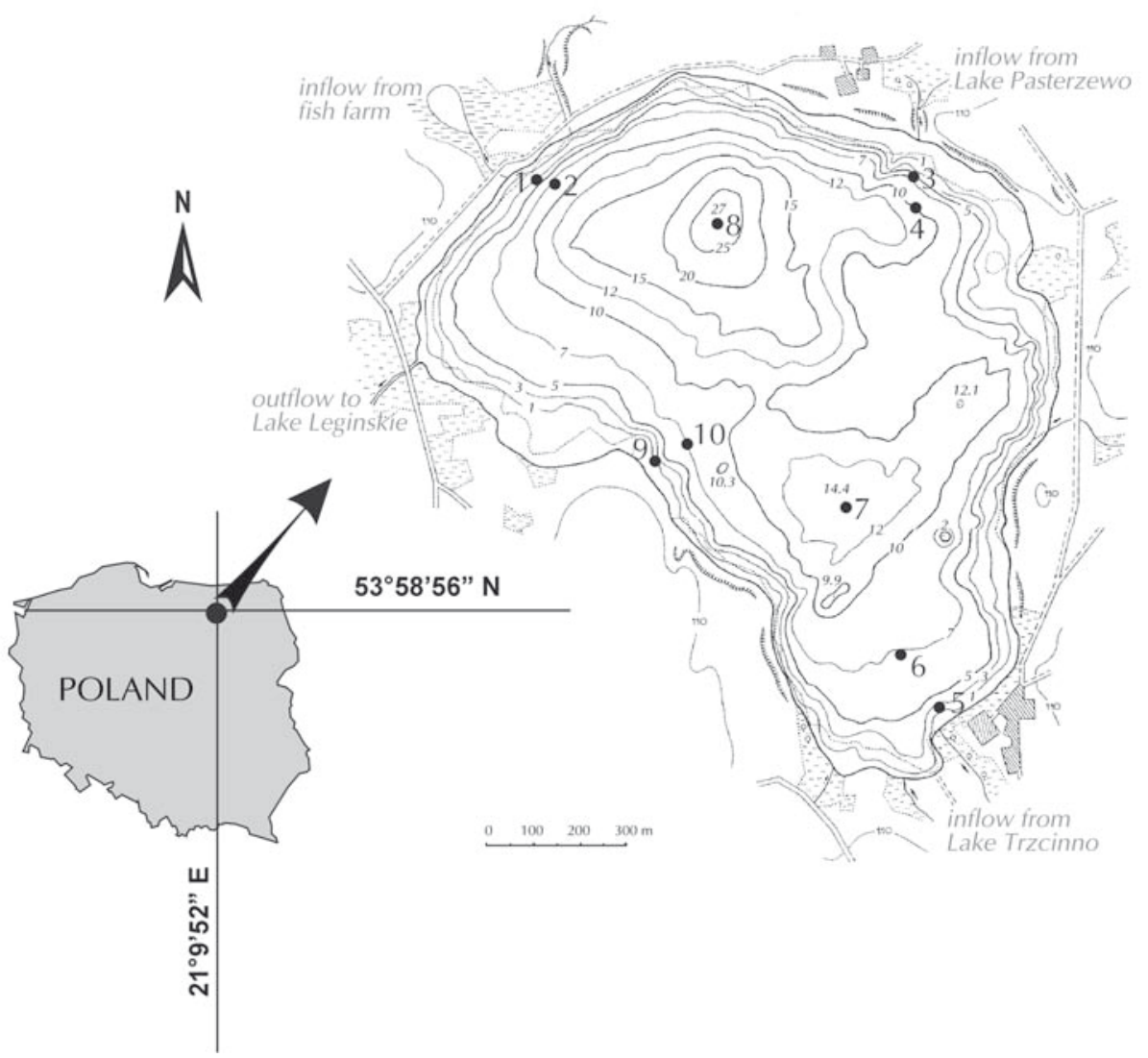

Fig. 1. Bathometric diagram and study site of Lake Widryńskie 


\section{Results and discussion}

The spatial variation of the chemical composition of bottom sediments depends, inter alia, on the morphometry of the reservoir. Deeper lakes, which periodically generate thermal stratification, will be characterized by different physicochemical conditions in different parts of the water. This allows for the existence of a whole mosaic of bottom sediments, with a clearly carved correlation between the way of the deposition of matter on the bottom and the depth of the reservoir.

Lake Widryńskie is a relatively deep basin (27 $\mathrm{m})$, with an irregular bottom configuration. An additional factor that enhances the diversity of the sediment composition is the flow-through nature of the lake. Inflows that feed the lake are located diametrically opposed and water runs from the nearby Lake Trzcinno and Lake Pasterzewo, which are characterized by different trophy. The catchment area of these inflows is dominated by mainly arable land and grass- land, plus inflows from Lake Trzcinno, which flows through the non-sewered village of Widryny.

Chemical analysis of sediment samples reflects their great diversity, especially the amount of macronutrients. With the exception of site 1 , where calcium carbonate sub-dominated, the studies showed the dominance of silica in the littoral and sub-littoral sediment. The profundal lake sediments showed that the major components were silica and calcium carbonate. According to the nomenclature given by Stangenberg (Choiński 1995), the examined sediments should therefore be classified as the silicate type (sampling sites $2,3,4,5,6,9,10)$ and the calcareous silicate type (sampling sites $1,7,8$ ).

The percentage of silica in sediment cores varied in the range from $36.9 \%$ dry weight (DW) in the profundal lake sediment collected at the deepest point to $91.5 \%$ dry weight at the third littoral site (Fig. 2).

Increased silica content in the littoral sediments could be related to the tributary and inflows that feed the reservoir from the catchment area. The

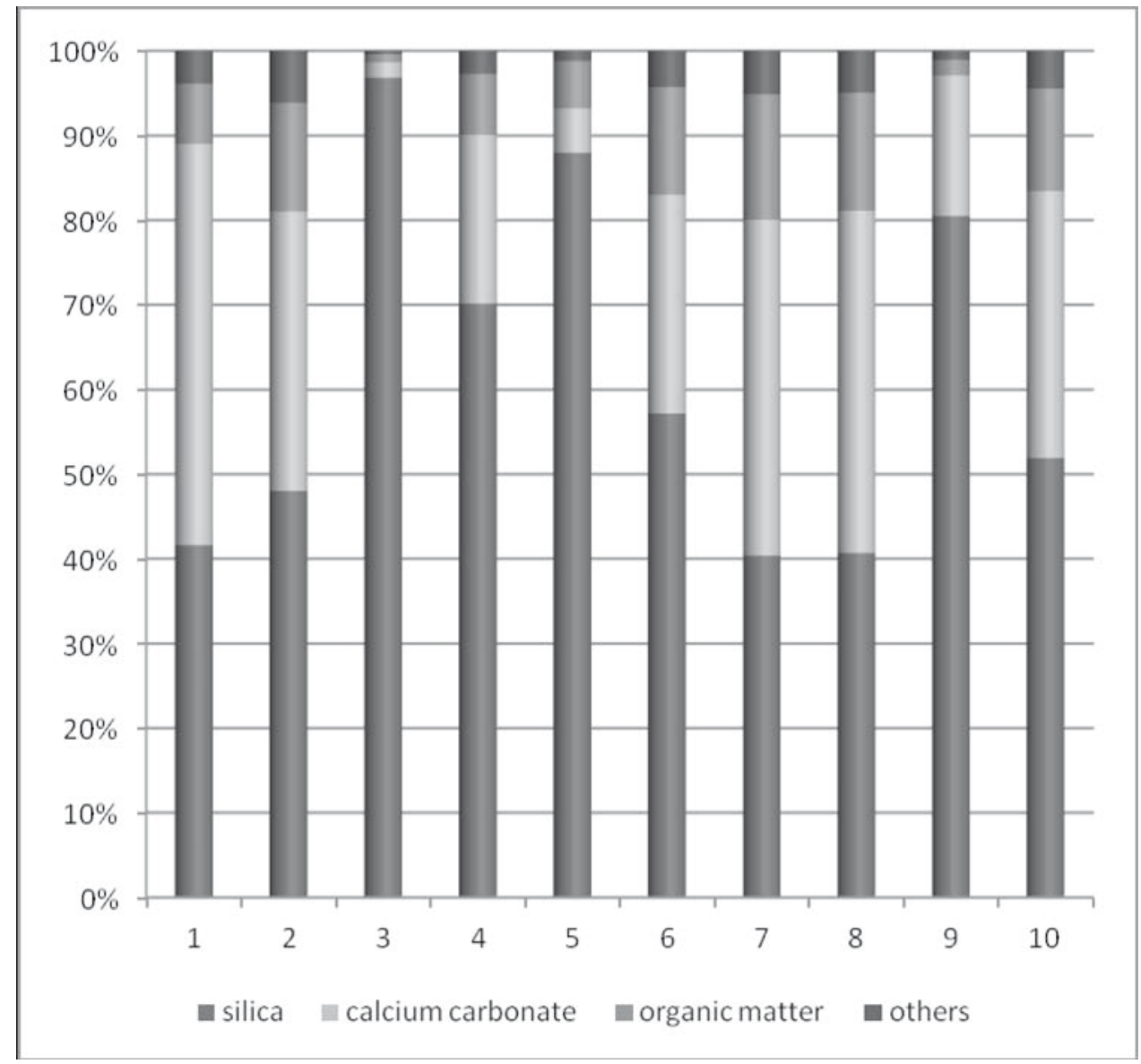

Fig. 2. Mean amounts of the bottom sediments components in Lake Widryńskie examination stations (in \% dry weight) 
highest content of silica was found on the sampling sites located in the areas of tributary inflows to Lake Widryńskie. Soils in the catchment areas of these tributaries are light and loose, resulting in highly eroded sections of sand. At the same time, there is no noticeable increase in the amount of this component in the watercourse from the fish ponds.

As in the case of silica in the bottom sediments of the reservoir, an increased content of calcium carbonate was found. This content ranged from $1.7 \%$ at site 3 to $43.1 \%$ dry weight at site 1 .

Calcium enters the lake from the catchment area as a product of physico-chemical and biological transformations (Kajak 2001). The total amount of calcium in the bottom sediments will be influenced by two processes: on the one hand, decalcification of water and, on the other, the dissolution of calcium carbonate in waters with high levels of carbon dioxide.

An important component of Lake Widryńskie sediments was also organic matter. The greatest amount of organic matter was contained in profundal sediments, up to $13.6 \%$ dry weight, while the smallest share of organic matter was at the littoral sampling sites, minimum $0.9 \%$ dry weight. The decrease in organic matter in the chemical composition of sediments may prove the limited tributaries of the catchment area and low productivity of the reservoir. The main sources of organic matter in the water column are particles of dead plants and animals, and produced non-mineralized substances which sink to its bottom
(Tadajewski 1966; Januszkiewicz 1980). The amount of organic matter is a result of the current trophy and conditions of mineralization. Taking into account the contribution of organic matter to the bottom sediment composition, the majority of it was found in the profundal sites.

In the sediments of Lake Widryńskie, clear differences were also found in the content of biogenic compounds - nitrogen and phosphorus. Biogenic elements are involved in a number of changes that occur in the aquatic system. They get into the reservoir along with runoff or tributaries, as well as by discharges of sewage into the lake, which in turn lead to increased nutrients in the reservoir.

Nitrogen in bottom sediments of eutrophic lakes occurs mainly as a component of indigenous and allochtonous organic matter (Gawrońska 1987). In the sediments of Lake Widryńskie, the nitrogen concentration fluctuated in the range from 0.13 to $0.85 \%$ dry weight (Fig. 3), a greater amount of nitrogen occurring in the sub-littoral sediments than the littoral ones, and the highest in the profundal sediments.

Nitrogen in the sediments of Lake Widryńskie occurs mainly as a component of organic matter, as demonstrated by the high correlation coefficient between these components $(n=10, r=0.9861)$.

The phosphorus content in sediments can be considered low (from 0.08 to $0.40 \%$ dry weight; Fig. 3). For comparison, in the bottom sediments of Lake Mutek, which together with Lake Widryńskie is part

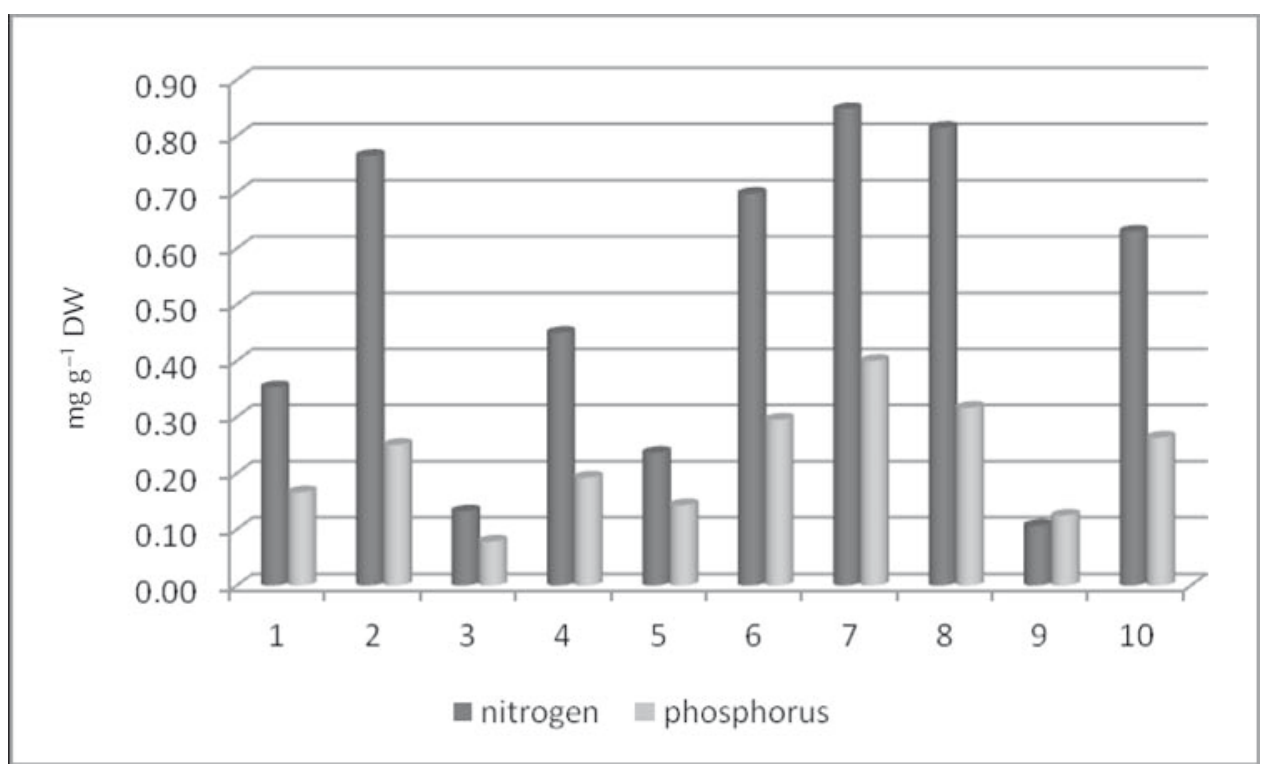

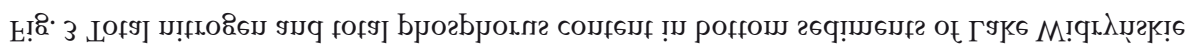


of the Legińskie Lake Complex, phosphorus varied between 0.36 to $1.53 \%$ dry weight (Gawrońska 1987).

Storage of phosphorus in the sediments is a complex process, conditioned by the chemical composition of the sorption complex, that is, the content of iron, aluminium, and manganese. The accumulation of phosphorus in the bottom sediments is determined by the processes of coagulation and sorption by the active compounds of these elements, and as a result of co-precipitation with calcium and sedimentation of organic matter and mineral dispersion (Januszkiewicz 1975; Forsberg 1989). The rate of phosphorus in the bottom sediments of the reservoir is also conditioned by the flow of water. Even slight currents may float the phosphorus absorbed by hydroxides and move it to more peaceful places (Sondergaard et al. 2001). In contrast, the release of phosphorus from bottom sediments will be determined mainly by temperature, $\mathrm{pH}$, redox potential and the microbial activity (Forsberg 1989).

The main component of the sorption complex of phosphorus in the bottom sediments in Lake Widryńskie was calcium. The bound fraction of calcium was $0.089 \mathrm{mg} \mathrm{P} \mathrm{g}^{-1} \mathrm{DW}$ to $1.134 \mathrm{mg} \mathrm{P} \mathrm{g}^{-1} \mathrm{DW}$ (Table 2). Because calcium phosphate complexes are very stable and have low solubility, the main mechanism of elimination of phosphorus from the water column of Lake Widryńskie will be co-precipitation with calcium carbonate. Phosphorus in combination with other elements appeared in small amounts.

Despite a small number of mobile fractions, bottom sediments of Lake Widryńskie can become a source of phosphorus in the inner enrichment process. A factor influencing the release of this element from

Table 2. Phosphorus fraction content in bottom sediments of Lake Widrynskie

\begin{tabular}{lcccc}
\hline & $\mathrm{P}_{\text {lab }}$ & $\mathrm{Al}-\mathrm{PO}_{4}$ & $\mathrm{Fe}-\mathrm{PO}_{4}$ & $\mathrm{Ca}-\mathrm{PO}_{4}$ \\
\cline { 2 - 5 } $\mathrm{mg} \mathrm{P} \mathrm{g}^{-1} \mathrm{DW}$ \\
\hline station 1 & 0.016 & 0.018 & 0.007 & 0.459 \\
station 2 & 0.016 & 0.019 & 0.016 & 0.576 \\
station 3 & 0.011 & 0.006 & 0.011 & 0.089 \\
station 4 & 0.020 & 0.015 & 0.020 & 0.388 \\
station 5 & 0.007 & 0.025 & 0.034 & 0.293 \\
station 6 & 0.017 & 0.027 & 0.036 & 0.664 \\
station 7 & 0.027 & 0.037 & 0.076 & 1.134 \\
station 8 & 0.015 & 0.019 & 0.055 & 0.823 \\
station 9 & 0.010 & 0.008 & 0.013 & 0.219 \\
station 10 & 0.016 & 0.022 & 0.021 & 0.650 \\
\hline
\end{tabular}

the layer of sediment is the already advanced eutrophic state of the reservoir and periodic oxygen deficits in profundal lake sediment. The studies conducted in 1969, 1978 and contemporarily, in 2002, indicate the fertilization of the near bottom waters during summer stratification of waters. Further directions of change may enhance the process of lake eutrophication.

\section{Conclusions}

The bottom sediments of Lake Widryńskie are of a silicate and calcium-silicate type. Littoral sediments were characterized by a higher proportion of silica in chemical composition than the sub-littoral and profundal sediments. The influence of inflows on the chemical composition of littoral sediments remains in compliance with their degree of contamination. Most organic matter and nutrients were deposited at the mouth of the inlet from Widryn and the inflows from a fish farm. A small amount of iron and aluminium in the composition of the bottom sediments meant that among the complexing elements the dominant role in controlling the pool of phosphorus in the ecosystem was played by calcium.

\section{References}

Bajkiewicz-Grabowska E., 2002, Obieg materii w ekosystemach rzeczno-jeziornych (Circulation of matter in the river-lake systems), Wyd. UW, Warszawa, p. 274 (in Polish, English summary).

Choiński A., 2007, Limnologia fizyczna Polski (Physical limnology of Poland), Wyd. Nauk. UAM, Poznań, p. 547 (in Polish).

Forsberg C., 1989, Importance of sediments in understanding nutrient cyclings in lakes, Hydrobiologia 176/177: 263-277.

Gawrońska H., 1987, Chemizm osadów dennych jeziora Mutek poddanego eksperymentowi sztucznego napowietrzania (Chemistry of the bottom sediments of Lake Mutek subjected to experiment of artificial aerating), Rocz. Nauk Roln. H 101(1): 39-52 (in Polish, English summary).

Golachowska J., 1977a, Prosta i szybka metoda oznaczania fosforu w osadach dennych jezior (A simple and rapid method for determining total phosphorus in bottom sediments of lakes), Rocz. Nauk. Rol. H. 98: 27-37 (in Polish, English summary).

Golachowska J., 1977b, Oznaczanie całkowitej zawartości fosforu mineralnego i organicznego w osadach dennych jezior (Determining total mineral and organic phosphorus content in bottom sediments of lakes), Rocz. Nauk. Rol. H 98(2): 39-49 (in Polish, English summary). 
Golachowska J., 1977c, Frakcjonowanie i oznaczanie mineralnych postaci fosforu w osadach dennych jezior (Fractionating and determining mineral forms of phosphorus in bottom sediments of lakes), Rocz. Nauk. Rol. H 98: 51-63 (in Polish, English summary).

Januszkiewicz T., 1970, Skład osadów głębinowych grupy jezior na Pojezierzu Kaszubskim (Chemical composition of bottom sediments in the group of the Kashubian Lake District), Rocz. Nauk Roln. H 92(2): 67-84.

Januszkiewicz T., 1975, Zagadnienia fosforu w eutrofizacji i ochronie wód (Issues of phosphorus in eutrophication and water protection), Gosp. Wod. 2(75): 58-65 (in Polish).

Januszkiewicz T., 1980, Chemistry of recent sediments of Grabowskie Lake in Kashubian Lake district in Northern Poland, Pol. Arch. Hydrobiol. 27(3): 319-336.

Kaiserli A., Voutsa D., Samara C., 2002, Phosphorus fractionation in lake sediments - Lakes Volvi and Koronia. N. Greece, Chemosphere 46(8): 1147-1155.

Kajak Z., 2001, Hydrobiologia-Limnologia. Ekosystemy wód śródlądowych (Hydrobiology-Limnology. Ecosystems of inland waters), PWN, Warszawa, p. 360 (in Polish).

Kondracki J., 2001, Geografia regionalna Polski (Physical geography of Poland), PWN, Warszawa, p. 440 (in Polish).

Pacini N., Gächter R., 1999, Speciation of riverine particulate phosphorus during rain events, Biogeochemistry 47: 87-109.

Pardo P., López-Sánchez J.F., Rauert G., 2003, Relationships between phosphorus fractionation and major components in sediments using the SMT harmonized extraction procedure, Anal. Bioanal. Chem. 376: 248-254.
[WIOŚ] Wojewódzki Inspektorat Ochrony Środowiska (Voivodship Inspectorate for Environment Protection), 2009, Raport o stanie środowiska województwa warmińsko-mazurskiego w 2008 roku (The Report on the state of the environment of Warmian-Masurian Voivodship in 2008), Biblioteka Monitoringu Środowiska, WIOŚ w Olsztynie, Olsztyn, p. 151 (in Polish).

Siwek H., Włodarczyk M., Brzostowska-Żelechowska D., Wachowiak M., 2009, Wpływ wybranych parametrów fizyczno-chemicznych osadu na zawartość nieorganicznych form fosforu w osadach dennych małych zbiorników polimiktycznych (Influence of chosen physicochemical parameters of sediment on contents of inorganic phosphorus compounds in bottom sediments of small polymictic lakes), Acta Agrophys. 13(2): 497-503 (in Polish, English summary).

Søndergaard M., Windolf J., E. Jeppesen, 2001, Retention and internal loadings of phosphorus in shallow, eutrophic lakes, The Scientific World J.1: 427-442.

Tadajewski A., 1966, Chemizm osadów dennych jeziora Sukiel i uwagi o jego faunie dennej (Chemistry of lake Sukiel sediments and remarks on its bottom fauna), Zesz. Nauk. WSR Olsztyn. 21(4): 689-710 (in Polish, English summary).

van Hullebusch E., Auvray F., Deluchat V., Chazal Ph.M., Baudu M., 2003, Phosphorus fractionation and short term mobility in the surface sediment of a shallow polymictic lake treated with low dose of alum (Courtille lake, France). Water Air Soil Pollut. 146(1-4): 75-91. 